\title{
Truncus Arteriosus: Surviving at 46 Years without Intervention
}

\author{
S Williams-Phillips
}

\begin{abstract}
The median survival of patients with truncus arteriosus is five weeks of age with rare cases reaching adulthood. The longest reported survivor with balanced ventricles, as the index case has, is 38 years of age. The index case is a 46-year old male with Type 3 truncus arteriosus. His case has never been documented in the English Literature as far as the author is aware.
\end{abstract}

Keywords: Pulmonary hypertension, systemic pulmonary collaterals, truncus arteriosus, single coronary artery

\section{Tronco Arterioso: Sobreviviendo a los 46 Años sin Intervención}

S Williams-Phillips

\begin{abstract}
RESUMEN
La mediana de la supervivencia de pacientes con tronco arterioso es cinco semanas de edad, siendo raros lo casos que alcanzan la edad adulta. El caso más viejo reportado con ventrículos balanceados, como en el caso índice, es un sobreviviente de 38 años de edad. El caso índice es un hombre de 46 años con tronco arterioso de tipo 3. Su caso nunca se ha documentado en la literatura en inglés, hasta donde el autor tiene noticias.
\end{abstract}

Palabras claves: Hipertensión pulmonar, colaterales pulmonares sistémicas, tronco arterioso, arteria coronaria única

West Indian Med J 2013; 62 (3): 273

\section{INTRODUCTION}

Persistent truncus arteriosus is a single great arterial vessel with the systemic, pulmonary and coronary circulation. There is no atretic aortic or pulmonary vessel. This was first confirmed by Buchanan in an autopsy report in 1864 (1-5). The three main types described by Collet and Edwards (1949) are differentiated by the origin of the right and left pulmonary arteries which also correlate with survival. With this specific anatomy, death occurred in $80-90 \%$ who present as "blue babies" in congestive cardiac failure usually in the first year of life. The identifiable, usual clinical cardiac causes of death were cardiopulmonary symptoms, intractable congestive cardiac failure aggravated when there is truncal regurgitation, arrhythmias, pulmonary hypertension or truncus dissection and rupture. Up to $50 \%$ of these patients have a defect in another system. The most common concomitant cardiac lesions are right aortic arch, patent ductus arteriosus,

From: Andrews Memorial Hospital, TAI Wing, 27 Hope Road, Kingston 10, Jamaica, West Indies.

Correspondence: Dr S Williams-Phillips, Andrews Memorial Hospital, TAI Wing, 27 Hope Road, Kingston 10, Jamaica, West Indies. E-mail: sandrap@cwjamaica.com. anomalous coronary artery ostium, truncal incompetence, secundum atrial septal defect, interruption of the aortic arch, and persistent left superior venae cava (1-9).

Survival has direct correlation to the type of anatomy and also the degree of pulmonary stenosis. Survival without pulmonary stenosis is usually not beyond the neonatal period. Naturally occurring pulmonary stenosis protects the lungs and is associated with increased longevity as this index case confirms (1-5).

The aetiology is unknown but is thought to be a defect or arrest in cono-truncal aortic septation during the embryological development of the heart. The influence of a genetic component modulated by environmental factors is shown in a documented case of two siblings with truncus arteriosus from a mother with patent ductus arteriosus (4, 5, 8-11). There is a noted incidence of $35-40 \%$ of cono-truncal abnormalities with chromosome microdeletion of 22q11.2 gene (9). DiGeorge syndrome has this microdeletion in up to $90 \%$, with the fluorescence in situ hybridization (FISH) assay, which is autosomal dominant with variable penetrance, and was confirmed in a case report of a mother with 22q11 deletion who had a newborn with an unusual form of truncus arteriosus (10-13). 
The index case is the longest survivor, as far as the author is aware, of truncus arteriosus Type $\mathrm{C}$ with balanced right and left ventricles.

\section{CASE REPORT}

A 46-year old male who completed high school education, is financially independent, active, self-employed and married for 26 years, was diagnosed at five months of age with truncus arteriosus after presenting with cyanosis and shortness of breath requiring antifailure therapy; this was discontinued by 17 years of age. There is no family history of congenital cardiac disease or of thalidomide use during pregnancy. $\mathrm{He}$ is the second of six children. He has no children.

Currently, there has been no history of recurrent hypercyanotic episodes, fainting syncope, orthopnea or pedal oedema. During the last three years, he has experienced breathlessness, chest pain and palpitations only on severe exertion. One episode of haemoptysis occurred three years previously. He normally functions at New York Heart Association (NYHA) functional classification 1 at rest and mild exertion and NYHA II on severe exertion, with complete recovery in two to three minutes of rest and deep breathing.

He has had repeated phlebotomy since 25 years of age at yearly intervals and for the last four years at approximately 6-9 month intervals which was required for symptomatic polycythemia.

Significant findings on examination were plethoric mucous membranes, central cyanosis, marked clubbing of fingers and toes, a small, short stature with asthenic build. His weight was $44.8 \mathrm{~kg}$ and height $160 \mathrm{~cm}$.

Saturation in air has consistently been $70-80 \%$ for the past three years with a current steady state of $77 \%$. The lowest saturation recorded was $53 \%$ when there was symptomatic polycythemia requiring phlebotomy six years ago. Pulse rate was $76 /$ minute, respiratory rate 20 /minute and blood pressure 115/69 mmHg.

Cardiovascular examination revealed: normal pulses, precordial bulge, parasternal heave, displaced apex beat in the $6^{\text {th }}$ left intercostal space in anterior axillary line, single second heart sound and a long ejection systolic murmur 3/6 at mid left sternal border. There were no continuous or diastolic murmurs. There were no additional heart sounds. There were no signs of right or left heart failure or hepatomegaly.

Current medications: sildenafil and furosemide were started at 43 years of age along with haematinics, iron sulfate, folate and vitamin B12 supplementation. Dietary supplementation of potassium was advised and preferred. Furosemide was initiated after intermittent bouts of pedal oedema, which occurred after long periods of standing and was relieved by elevation of the feet.

His most current haematology results showed: haemoglobin $14.5 \mathrm{~g} / \mathrm{dL}$, packed cell volume $56 \mathrm{~L} / \mathrm{L}$. Liver function test, urea and electrolytes, bleeding indices pro- thrombin time and partial thromboplastin time, lipid profile, thyroid function tests, fasting glucose and prostatic specific antigen were all normal. Maximum haemoglobin of 21.3 $\mathrm{g} / \mathrm{dL}$ was noted at 25 years of age with symptoms of polycythemia with hyper-viscosity syndrome requiring phlebotomy for the first time.

Electrocardiogram showed: sinus rhythm, right axis deviation, biventricular hypertrophy, inverted $\mathrm{T}$ waves in $\mathrm{V} 1$ to V6, QR in V1, normal QRS duration, no significant ST segment anomaly, normal $\mathrm{P}$ axis and superior $\mathrm{T}$ axis.

Chest X-ray confirmed clinical cardiomegaly with an increase in the cardiothoracic ratio, dilated pulmonary arteries with variable vascularity as noted by plethora in right upper lung fields and oligaemia and pruning in left lower lung fields, and variation of vascularity indicating multifocal pulmonary blood supply.

Transthoracic echocardiogram (TTE) showed: situs solitus/atrioventricular concordance/truncus arteriosus type A, persistent left superior vena cavae. There was no atrial septal defect or interatrial communication. Competent atrioventricular valves and a large, non-restrictive ventricular septal defect (VSD), extending from trabecular to outlet interventricular septum were noted.

He had bi-ventricular anatomy with marked hypertrophy of right and left ventricles, normal right and left ventricular function. There was bilateral flow across the ventricular defect but this was predominantly left to right. There was a trileaflet truncal valve with no stenosis or regugitation. The truncal valve originated predominantly from the right ventricle (Figure). Until TEE, there was thought to

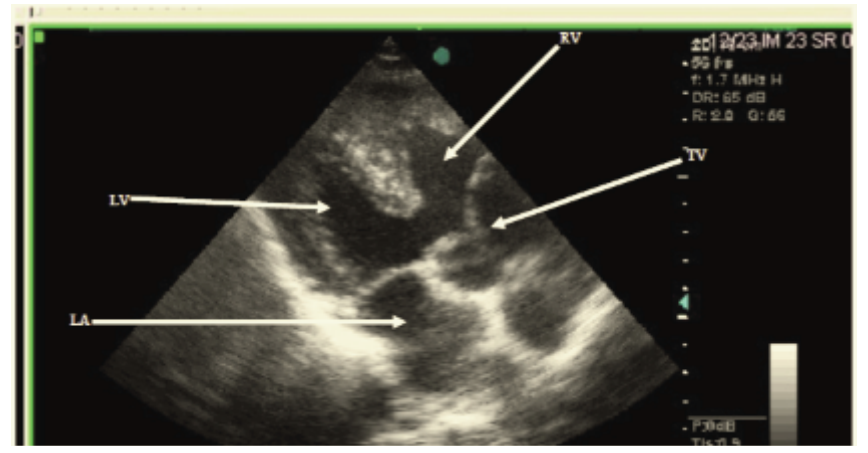

Figure: Transthoracic echocardiogram parasternal long axis view. Large ventricular septal defect (VSD); truncal valve (TV) over right ventricle $(\mathrm{RV}) . \mathrm{LA}=$ left artery, $\mathrm{LV}=$ left ventricle.

be stenosis of the origin of the main pulmonary arterial trunk originating from the left posterior aspect of truncal trunk. A definitive ostium coronary artery location was not seen.

Four systemic pulmonary (S-P) collaterals were noted on the anterior aspect of the descending aorta in suprasternal view. There was a left sided aortic arch, good ventricular function with normal shortening fraction of $38 \%$. Since 2006, his shortening fraction has been documented between $29 \%$ and $44 \%$ (normal 28\%-48\%). Transoesophageal echo- 
cardiogram (TEE) confirmed: situs solitus, atrioventricular concordance, truncus arteriosus Type $\mathrm{C}$, the same findings as transthoracic echocardiogram. The additional clarifying features not noted on TTE were: single coronary artery originating from right coronary sinus, stenosis of origin of left pulmonary artery originating from left posterior aspect of truncal trunk, stenosis of origin of right pulmonary artery originating from right posterior aspect of truncal trunk seen in transgastric great arterial view.

Diagnostic cardiac catheterization with no angiography was done to determine reversibility of pulmonary hypertension. This followed standard procedure and use of prophylactic antibiotics. He had a saturation of $77 \%$ in air. Severe right and left pulmonary artery stenosis prevented the catheter from entering the pulmonary arteries. Three systemic pulmonary collaterals were detected on the anterior aspect of the descending aorta, with an end hole catheter, and showed systemic pressures in all three. There were systemic pressures in the right and left ventricles.

\section{DISCUSSION}

This index case is not only interesting and has made history because of the age of survival, but also because of the multifocal blood supply of the lungs and the inherent severe pulmonary stenosis sparing that area of the lung from secondary damage from pulmonary hypertension. He also had no other anomaly outside of his cardiovascular system. His single coronary artery with normal distribution of right and left coronary vessels is of no clinical significance (1-15).

The index case had competent atrioventricular and truncal valves, stenotic pulmonary artery flow which has protected his lungs thus far, hence his longevity. Systemic pulmonary collaterals indicated multifocal blood flow to lung segments. This was also noted on chest X-ray where the vascularity varies in the lung fields.

Clinically he has Eisenmenger syndrome hence cardiac catheterization was done to provide an accurate assessment of pressures and its reversibility, in the right and left pulmonary arteries and S-P collateral separately. Angiography was not done because of the increased possibility of pulmonary vasoconstriction, systemic hypotension and arrhythmias when done in the presence of pulmonary hypertension (1-22).

The exact structural delineation of the heart of the index case was obtained by TTE and TEE which had helped to define more clearly the type of truncus arteriosus by showing the origins of the right and left pulmonary arteries and had also shown an anomalous single coronary artery. Coronary artery abnormalities are more common in truncus arteriosus, and coronary angiography was not needed for further delineation.

Since the first successful intracardiac repair in 1962 at the University of Michigan (4), there have been many advances made in medical and surgical management of the rare and complex congenital cardiac lesions and his cardiac anatomy would allow biventricular repair, unifocalization of pulmonary arteries and valved right ventricle pulmonary artery conduit with ligation of S-P collaterals $(4,5,12,18$ 21). Monro et al (23) had a 10-year freedom from reoperations and survival of truncus arteriosus at $54 \%$ and $71 \%$, respectively. This would have been necessary as right ventricular outflow valve replacement at the end of the valve's life span of four to six years would have been inevitable whilst he was growing until an adult homograft or mechanical valve could be used $(12,18-27)$. His innate cardiac structure has outlived what cardiac surgeons have achieved.

An episode of haemoptysis is a clinically ominous sign indicating grade 6 stage of Heath and Edwards classification of pulmonary vascular disease in a segment of his lung (5, 26).

Diagnosis of truncus arteriosus with delineation of structural co-morbidities is now available non-invasively with computed tomography (CT) and cardiovascular magnetic resonance imaging (MRI). There have been reported cases of pre-natal diagnosis of truncus arteriosus $(11,28-30)$.

The index patient, whose level of longevity has never been documented before, can be a guide in the refinement of the development of the early intervention and surgical management of truncus arteriosus in neonates. Early coil occlusion of the S-P collaterals would have led to reduced likelihood of pulmonary hypertension, if this procedure was available, as this appears from his anatomy and clinical progress to be the main source of development of pulmonary hypertension in the segments of the lung it supplies.

This report highlighted an extremely rare case of a 46 year-old male diagnosed with truncus arteriosus with no intervention and still functioning at NHYA 1 . The patient will be followed-up to determine his true longevity.

\section{REFERENCES}

1. Hicken P, Evans D, Heath D. Persistent truncus arteriosus with survival to the age of 38 years. Brit Heart J 1966; 28: 284-6.

2. Morgan JR, Kearney DJ, Hagan AD. Type 1 truncus arteriosus in an adult. Chest 1972; 62: 501-4.

3. McCue CM, Lester RG, Bosher LH, Mauck HP. Persistent truncus arteriosus, a clinical correlation with the pathologic anatomy. Chest 1964; 46: 507-23.

4. Kirklin JW, Barrett-Boyes BG. Truncus arteriosus. In: Cardiac Surgery. Vol 2. New York: Churchill Livingstone Inc; 1993: 1131.

5. Anderson RH, Macartney FJ, Shinebourne EA, Tynan M. Truncus arteriosus. In: Paediatric Cardiology. Vol 2. New York: Churchill Livingstone Inc; 1987: 913.

6. Gutierrez PS, Binotto MA, Aiello VD, Mansur AJ. Chest pain in an adult with truncus arteriosus communis. Am J Cardiol 2004; 93: 272-3.

7. Harris HA, Thomson GC. Persistent truncus arteriosus communis with microphthalmos, orbital cyst and polydactyly. Arch Dis Child 1937: 12: 59-66.

8. Porter I, Vacek J. Single ventricle with persistent truncus arteriosus as two rare entities in an adult patient: a case report. J Med Case Reports 2008; 2: 184.

9. Guenther F, Frydrychowicz A, Bode C, Geibel A. Persistent truncus arteriosus: a rare finding in adults. Cardiovascular Flashlight. Eur Heart J 2009; 30: 1154 . 
10. Goodyear JE. Persistent truncus arteriosus in two siblings. Brit Heart J 1960; 23: 194-6.

11. Phelps CM, Da Cruz E, Fagan T, Younoszai AK, Tissot C. Anterior origin of the main pulmonary artery from the arterial valvar sinus. Circulation 2009; 119: 624-7.

12. Chiaw TH, San TR, Le TJ. An adult with truncus arteriosus and unilateral pulmonary hypertension. Congenit Heart Dis 2007; 2: 433-7.

13. Beauchesne LM, Warnes CA, Connolly HM, Amnash NM, Grogan M, Jalal SM et al. Prevalence and clinical manifestations of 22q11.2 microdeletion in adults with selected conotruncal anomalies. J Am Coll Cardiol 2005; 45: 595-8.

14. Victorica BE, Gessner IH, Van Mierop LHS, Schiebler GL. Persistent truncus arteriosus: an electrovectorcardiographic study in 14 infants. Dis Chest 1968; 54: 100-4.

15. Victorica BE, Gessner IH, Schiebler GL. Phonocardiographic findings in persistent truncus arteriosus. Br Heart J 1968; 30: 812-6.

16. Rogers MA, Winship WS, Coleman AJ. Correction of persistent truncus arteriosus. Thorax 1971; 26: 115-18.

17. Van deer Horst RL, Gotsman MS. Type $3 \mathrm{c}$ truncus arteriosus. Br Heart J 1974; 36: 1046-8.

18. Bricker DL, King SM, Edwards JE. Anomalous aortic origin of the right and left pulmonary arteries in a normally septated truncus arteriosus. Chest 1975; 68: 591-4.

19. Cree IC. Truncus arteriosus and a single ventricle. Br Heart J 1956; 18: 553-6.

20. Marshall R. Persisent truncus arteriosus. Br Heart J 1943; 5: 194-6.

21. Zimmerman HM. A congenital anomaly of the heart: truncus arteriosus communis. Am J Pathol 1927; 3: 617-21.

22. Finley KH. A congenital anomaly of the heart (truncus arteriosus communis with subacute endocarditis). Am J Pathol 1930; 6: 317-23.
23. Monro JL, Alexiou C, Salmon AP, Keeton BR. Reoperations and survival after primary repair of congenital heart defects in children. J Thorac Cardiovasc Surg 2003; 126: 511-19.

24. Forbess JM, Shah AS, St Louis JD, Jaggers JJ, Ungerleider RM. Cryopreserved homografts in the pulmonary position: determinants of durability. Ann Thorac Surg 2001; 71: 54-60.

25. Brown JW, Ruzmetov M, Rodefeld MD, Vijay P, Darragh RK. Valved bovine jugular vein conduits for right ventricular outflow tract reconstruction in children: an attractive alternative to pulmonary homograft. Ann Thorac Surg 2006; 82: 909-16.

26. Stulak JM, Dearani JA, Burkhart HM, Sundt TM, Connolly HM, Schaff HV. Does the dilated ascending aorta in an adult with congenital heart disease require intervention? J Thorac Cardiovasc Surg 2010; 140 (Suppl 6): S52-7; discussion S86-91.

27. Anderson RH, Becker AE. Interaction between heart and lungs. In: The Heart - Structure in Health and Disease. London: Gower Medical Publishing; 1992: 4.9.

28. Verhaert D, Arruda J, Thavendiranathan P, Cook SC, Raman SV. Truncus arteriosus with aortic arch interruption: cardiovascular magnetic resonance findings in the unrepaired adult. J Cardiovasc Magn Reson 2010; 12: 16.

29. Yildirim A, Karabulut N, Dogan S, Herek D. Congenital thoracic arterial anomalies: a CT overview. Diagn Interv Radiol 2011; 17: 352 62.

30. Lopes LM, da Silva JP, da Fonseca L, Meiken S, Salvador ABC, Fernandes GSDS. Atypical truncus arteriosus operated at 28 years of age: importance of differential diagnosis. Arq Bras Cardiol 2011; 97: e29-e32. 